DOI https://doi.org/10.18551/rjoas.2018-09.33

\title{
THE IMPACT REGULATION OF TRADE MINISTER OF THE REPUBLIC OF INDONESIA \#82 OF 2017 AGAINST MARKET REACTIONS IN INDONESIA STOCK EXCHANGE
}

\author{
Utama Kadek Budi Satria*, Purbawangsa Ida Bagus Anom \\ University of Udayana, Bali, Indonesia \\ *E-mail: budisatriia@gmail.com
}

\begin{abstract}
This study aims to determine the impact and analyze differences in average abnormal returns before and after the issuance of trade minister regulation number 82 of 2017 dated December 8, 2017 on shipping \& logistics sub-sectors in the Indonesia Stock Exchange. The results showed the market reaction at $t-4, t+3$ and $t+4$, but it was suspected that there was a leakage of information indicated by the presence of a significance value at $t-4$. The results of this study also showed that there were no significant differences before and after the publication of the regulation of the Minister of Trade of the Republic of Indonesia number 82 of 2017.
\end{abstract}

\section{KEY WORDS}

Abnormal return, event study, market efficiency, capital market.

Research on market reactions is closely related to Market Efficiency. How a market reacts to information to achieve a new equilibrium price is important. If the market reacts quickly and accurately to achieve a new balance that fully reflects the available information, then this market condition is called an efficient market (Jogiyanto, 2016). The relationship between market theory which describes equilibrium with the concept of an efficient market that tries to explain how the market processes information to lead to a new equilibrium position. Fama (1970), presents three main forms of market efficiency, namely, weak form of market efficiency, semi-strong form of the market efficiency and strong form of market efficiency.

The impact assessment of the issuance of the Republic of Indonesia trade minister's regulation number 82 of 2017 on the Indonesian capital market is an event study. Jogiyanto (2016) mentions that event studies (studies) are studies that study the market reaction to an event (event) whose information is published as an announcement. Event studies can be used to test the information content of an announcement.

Information content testing must be done to be able to see the reaction of an announcement. If the announcement contains information, the market is expected to react when the announcement is received by the market. Market reaction can be seen from changes in prices of the securities concerned. This reaction can be tested using abnormal returns. Announcements are said to contain information content if one or more market participants can enjoy high abnormal returns or low returns from real returns in a long time (Jogiyanto, 2016).

Abnormal return is the difference between actual return and expected return. The test will involve an estimation period which is generally the period before the event. The event period is also called the observation period or window period (event period). In this study the period event used was 111 days, namely on July 8, 2017 until December 15, 2017.

This research uses shipping \& logistics sub-sector as a sample. The selection of research locations is because researchers see opportunities for companies incorporated in the sub-sector. Export and import transport activities are still dominated by foreign vessels in 2016.

In addition to the phenomena that have been described, one of the reasons behind this research is the existence of previous research gap research that has examined the market reaction due to political events. Research by Ghanem and Rosvall (2014), Mahmood et al. (2014), Najaf et al. (2014), Kabiru et al. (2015), Pamungkas, et al (2015), Ramesh and 
Rajumesh (2015), Sasongko, et al (2015), Yuliana and Sudana (2015), Hatmanti and Bambang (2017) get results that there are significant abnormal returns in the period after the event politics studied. While different results are found in Hung (2013), Pratama, et al (2015), Yuniarthi and Sujana (2016) Octafilia (2016), and Wong and Hooy (2016) found results that there were no significant abnormal returns in the period after the event politics studied.

\section{LITERATURE REVIEW}

Both direct and indirect investments can be made in the capital market. In general, long-term investments that are traded in the capital market, either in the form of fixed income securities, and equity securities. Through various types of financial instruments, investors can carry out investment portfolios in accordance with the expected level of profit and risk that can be borne. Based on the information available, investors can make the right decisions in investing with certain risks. Among securities that can be traded in the capital market, stocks are the most widely known. Investment in shares in the capital market can provide unlimited profits for investors. If the stock issuing company or issuer is able to generate large profits, it is possible that the shareholders will enjoy large profits which are distributed in the form of dividends. The advantage of stock investment is also obtained from capital gains or the difference between the price when selling and the price when buying.

Jogiyanto (2016) also defines that an efficient market if market conditions react quickly and accurately to achieve a new equilibrium price that fully reflects the available information. The faster new information is reflected in the more efficient securities market price of the capital market, so that it is difficult and even impossible for investors to obtain a constant level of income above normal, ie the realized income level is higher than the expected level of income by trading transactions in the capital market.

Fama (1970) divides market efficiency into three categories, namely:

- Testing of weak form market efficiency or testing of Return estimation (test for return predictability);

- Semi-strong form market efficiency tests or event studies;

- Tests of strong market efficiency or testing of private information (test for private information).

Jogiyanto (2016: 606) also said that the testing of information content and testing the efficiency of the semi-strong form market were two different tests. Testing the content of information is intended to see the reaction of an announcement. If the announcement contains information, the market is expected to react when the announcement is received by the market. This market reaction can be measured using return as the value of price changes or by using abnormal returns. If using abnormal returns, it can be said that an announcement containing information content will give abnormal returns to the market. Conversely, if it does not contain information, it will not give abnormal returns to the market.

Tandelilin (2010: 18) states that the capital market or funds or securities traded in the capital market are generally in the form of stocks and bonds. Shares are defined as a sign of ownership or ownership of a person in a company or business entity. Investors make investments in the capital market by buying shares and selling them again for profit. The level of profit or return received by an investor from shares traded in the capital market (shares of companies going public) are usually termed stock returns (Jogiyanto, 2016: 189).

Based on the regulation of the Minister of Trade of the Republic of Indonesia number 82 of 2017 what is meant by the Navy is a transportation activity which according to its activities serves sea transportation activities. National sea transport companies are marine companies that are Indonesian legal entities that carry out sea transportation activities in Indonesian waters and or from and to ports abroad. Based on the regulation of the Minister of Trade of the Republic of Indonesia number 82 of 2017 Article 3 includes:

- Exporters who export coal and / or CPO, their transportation is obliged to use Sea Transportation controlled by the National Sea Transport Company;

- Importers who import rice, their transportation is obliged to use sea transportation controlled by the National Sea Transport Company; 
- Importers who import goods for the procurement of government goods, their transportation must use Sea Transportation controlled by the National Sea Transport Company.

Research hypothesis:

$\mathrm{H} 1$ : There is a significant average abnormal return in the issuance of the regulation of the Minister of Trade of the Republic of Indonesia number 82 of 2017.

$\mathrm{H} 2$ : There are differences in average abnormal returns before and after the publication of the regulation of the Minister of Trade of the Republic of Indonesia number 82 of 2017.

\section{METHODS OF RESEARCH} 610):

Abnormal returns can be calculated with the following formulations (Jogiyanto, 2016:

$$
A R_{i t}=R_{i t}-E\left[R_{i t}\right]
$$

Where: $A R I T=$ Abnormal return of securities to the period of the t-event; $R$ it $=$ The actual return that occurs for the securities in the period of the t-event; $E$ [Rit] = Return to the $1 \mathrm{st}$ securities expectation for the t-event period.

The population of this study was Shipping \& Logistics sub-companies listed on the IDX as many as 21 companies. The sampling technique in this study used purposive sampling where the samples were taken intentionally according to the research needs. The sample used is shares listed on the Indonesia Stock Exchange with the following sampling criteria:

- Companies that do not conduct corporate actions (share dividends, conduct stock split, or merger) in the observation period and event period;

- Companies that have listed during the observation period and event period;

- Companies that provide complete historical data that can be viewed through web finance.yahoo.com;

- Companies that are actively traded during the observation period and event period.

In this study the data analysis method used is a comparative method. Comparative analysis method or different test is a form of variable analysis to find out the differences between two or more groups of data (Misbahuddin, 2013). In this study will examine the difference between average abnormal returns before and after the occurrence of the issuance of trade minister's regulation number 82 of 2017. The data processing results will be compared between $t$-value and t-table to find out a significant difference between before and after the event.

The first step taken in testing the hypothesis I is to determine the observation period. Because the abnormal return calculation uses a market model, the observation period consists of the estimated period and window period. The estimated period used is 100 days of shares starting from July 8, 2017 until November 29, 2017. After finding the estimated period, the steps taken are to determine the window period. In this study the window period used was 11 days consisting of 5 days before the event, the day of the event and 5 days after the event, namely November 30, 2017, December 8, 2017 and December 15, 2017.

Five days is taken because it is considered that the period is the best period to see the market reaction. If the estimated period is taken too short, it is feared that there is a long market reaction but cannot be detected in the research conducted, whereas if the period taken is too long, there are other significant events affecting the results of the study.

The next step that must be done to test hypothesis $I$ is to calculate abnormal return (excess return), where the abnormal return of a stock is the difference between actual return and expected return. To calculate abnormal returns are as follows:

$$
A R_{i t}=R_{i t}-E\left(R_{i t}\right)
$$

Where: ARit: Abnormal stock return I on day t; Rit: stock return for stock I on day t; $E$ (Rit): expected return for stock I on day $t$. 
To calculate stock returns using the following formula:

$$
R_{i t}=\frac{P_{t}-P_{t-1}}{P_{t-1}}
$$

Where: Rit: actual return; Pt: stock price on day t; Pt-1: stock price on the previous day.

To calculate the expected return of $E$ (Rit) this must first be determined in advance the estimation technique to determine this abnormal return. In this study used a market model, because the market model is a more sophisticated technique or model where the market model illustrates the relationship between securities and markets that are formed using simple regression techniques with equations, (Jogiyanto, 2016):

$$
E\left(R_{i t}\right)=\alpha_{i}+\beta_{i} * R_{m t}+\varepsilon_{i}
$$

Where: $E($ Rit $)=$ expected return for shares $\mathrm{i}$ on day $\mathrm{t}$; Rmt $=$ rate of return from the market index on day $\mathrm{t}$; ai = intercept, is a constant or expectation value of independent securities returns to market returns; $\beta \mathrm{i}=$ stock beta which is a coefficient that measures changes in $\mathrm{Ri}$ due to changes in Rm.

Market Return $(\mathrm{Rm})$ is sought using the basis of the Composite Stock Price Index (CSPI). The $\mathrm{JCl}$ data that will be used is during the event period. Testing for abnormal returns or not done by each security, but carried out in aggregate by examining the average abnormal return for all securities in a cross section for each day of the event period. By using the market model produced in the estimation period, the abnormal return for the event period can be calculated by the following formula:

$$
A R_{i t}=R_{i t}-E\left(R_{i t}\right)
$$

To test the null hypothesis $(\mathrm{H} 0)$ which states that the abnormal return is equal to zero, the $t$ test is used, while standardization of abnormal returns (SAR) is used as standard. In this study the $t$ test used to test the null hypothesis explains that abnormal returns equal to zero are as follows:

$$
\begin{aligned}
& S A R_{\text {it }}=\frac{A R}{\text { Estimation standard error }} \\
& T_{\text {value }}=\frac{A R}{\text { Estimation standard error }}
\end{aligned}
$$

Hypothesis testing is done by comparing t-value with t-table to see events that have a significant impact on the Indonesian capital market, in testing the level of abnormal return significance is used $5 \%$.

The step taken in testing hypothesis II is determining the average abnormal return. The abnormal value of stock return in each period is the same and the average is calculated so that the average abnormal return results are obtained. The next step is to test the difference in abnormal return average before and after using a different test. The basis for decision making is as follows:

If the significance value is $<0.05$, the hypothesis I is accepted, meaning that there is a significant difference in the average abnormal return before and after the publication of the regulation of the Minister of Trade of the Republic of Indonesia number 82 of 2017;

If the significance value is $>0.05$, hypothesis 1 is rejected, meaning that there is no significant difference in the average abnormal return before and after the publication of the regulation of the Minister of Trade of the Republic of Indonesia number 82 of 2017.

\section{RESULTS OF STUDY}

The following is the calculation of the average abnormal return and cumulative average abnormal return on events: 
Table 1 - Average abnormal return and cumulative average abnormal return

\begin{tabular}{c|c|c}
\hline Period & Average abnormal return & Cumulative Average Abnormal Return \\
\hline-5 & 0,001 & 0,001 \\
\hline-4 & $-0,035$ & $-0,034$ \\
\hline-3 & $-0,028$ & $-0,062$ \\
\hline-2 & $-0,012$ & $-0,074$ \\
\hline-1 & $-0,008$ & $-0,083$ \\
\hline 0 & 0,004 & $-0,079$ \\
\hline 1 & $-0,029$ & $-0,108$ \\
\hline 2 & $-0,004$ & $-0,112$ \\
\hline 3 & 0,032 & $-0,080$ \\
\hline 4 & $-0,028$ & $-0,108$ \\
\hline 5 & 0,010 & $-0,098$ \\
\hline
\end{tabular}

Source: Primary Data, 2018.

The calculation results of Table 1 are used to compile a graph with the time period as the $\mathrm{X}$-axis and the CAAR (cumulative average abnormal return) value as the $\mathrm{Y}$-axis. The following is a graph showing the movement of CAAR during the event period:

The basis of decision making in hypothesis $\mathrm{I}$ is done by comparing $\mathrm{t}$-value with t-table to see events that have a significant impact on the Indonesian capital market, in testing the level of abnormal return significance is used $5 \%$. The value of $t$ table is 2,145 .

Table 2 - Average value of abnormal return and t-value of companies in the event period

\begin{tabular}{c|c|c|c}
\hline Period & AAR & T value & Description \\
\hline-5 & 0.001 & 0,097 & Not sig. \\
\hline-4 & -0.035 & $-2,442$ & Not sig. \\
\hline-3 & -0.028 & $-1,833$ & Not sig. \\
\hline-2 & -0.012 & $-0,706$ & Not sig. \\
\hline-1 & -0.008 & $-0,921$ & Not sig. \\
\hline 0 & 0.004 & 0,820 & Not sig. \\
\hline 1 & -0.029 & $-2,104$ & Sig. \\
\hline 2 & -0.004 & $-0,550$ & Sig. \\
\hline 3 & 0.032 & 2,406 & Not Sig.
\end{tabular}

Source: Primary Data, 2018.

Table 2 shows the results of average abnormal returns for 15 sample companies and $t$ test (t-value) in the days of the event period. AAR positive in the event period only occurs at $\mathrm{t}-5, \mathrm{t} 0, \mathrm{t}+3$ and $\mathrm{t}+5$. AAR which is statistically significant only occurs at $\mathrm{t}-4, \mathrm{t}+3$ and $\mathrm{t}+4$. This shows that the issue of the issuance of the Republic of Indonesia trade minister's regulation number 82 of 2017 has information, but the information has leaked and investors have reacted before the event took place.

t-test on the difference in average abnormal returns before and after the publication of the regulation of the Minister of Trade of the Republic of Indonesia number 82 of 2017 shows the following results:

Table 3 - T-Test of Average Abnormal Return Before and After the Publication of the Regulation of the Minister of Trade of the Republic of Indonesia Number 82 of 2017

\begin{tabular}{c|c|c|c}
\hline $\mathrm{n} / \mathrm{n}$ & $\mathrm{N}$ & Correlation & Sig. \\
\hline AAR before and after & 5 & $-0,547$ & 0,340 \\
\hline
\end{tabular}

Source: Primary data, 2018.

Based on the results of data processing using SPSS 21.0 in table 5.6 it is known that Sig. is 0.340 , which means that $0.340>0.05$, then $\mathrm{H} 1$ is rejected and $\mathrm{HO}$ is accepted, ie there is no significant difference in average abnormal returns before and after the issuance of the 
Republic of Indonesia trade minister's regulation number 82 of 2017 on the shipping \& logistics sub-sectors in the Exchange Indonesian securities.

\section{CONCLUSION AND SUGGESTIONS}

The Indonesian capital market reacted to the issue of the Republic of Indonesia trade minister's regulation number 82 of 2017 . This is evidenced by the significance value at $t-4, t$ +3 and $t+4$, but the information leak caused the market to react before the event took place.

There is no difference in average abnormal returns between before and after the issuance of the Republic of Indonesia's trade minister's regulation number 82 of 2017 on the Indonesia Stock Exchange. This means that capital market players have obtained information and are more vigilant in calculating long-term possibilities, so that they are not in a hurry to take action to buy and sell shares.

For shareholders in the Indonesia Stock Exchange (IDX) who found information about the trade minister's regulation of the Republic of Indonesia going forward, they can always make buying and selling decisions on shares that have an impact on the regulation of the Republic of Indonesia trade minister.

For future researchers who want to do similar research, you should observe capital markets outside Indonesia such as the Nikkei 225 Index, Hang Seng Index, Shanghai Composite Index, Straits Times Index, FTSE 100 Index, Dow Jones Index, S \& P 500 Index or NASDAQ to see if foreign capital markets have the same impact as Indonesia.

\section{REFERENCES}

1. Fama, E,F. 1970. Efficient Capital Markets: a Review of Theory and Empirical Work. Journal of Finance, Vol. 25, No. 2, pp. 383-417.

2. Hatmanti, Aulia dan Bambang S. 2017. Pengaruh Pelantikan Kabinet Kerja Hasil Reshuffle Jilid II terhadap Harga Saham LQ-45. Jurnal Economia, Vol. 13, No.1, pp. 1-13

3. Hung, L. C. 2013. US Presidential Elections and the Taiwanese Stock Market. Journal Institute of International Relations, Vol.49, No.1, pp. 71-97.

4. Jogiyanto, Hartono. 2016. Teori Portofolio dan Analisis Investasi. Edisi ke 11. Yogyakarta: BPFE.

5. Kabiru, JN., Duncan E O., dan Hellen W K. 2015. The Effect of General Elections on Stock Returns at the Nairobi Securities Exchange. European Scientific Journal, Vol. 11, No. 28, pp. 435-460.

6. Mahmood, S., Muhammad I., Saeed I., Muhammad K., dan Ali I. 2014. Impact of Political Events on Stock Market: Evidence from Pakistan. Journal of Asian Business Strategy, Vol. 4, No. 12, pp. 163-174.

7. Octafilia, Yusnita. 2016. Dampak Pemilihan Presiden RI tahun 2014 terhadap Abnormal Return dan Trading Volume Activity di Bursa Efek Indonesia. E-Journal Universitas Pelita Indonesia, Vol.1, No.1, pp. 100-110.

8. Pratama, I G B., N. K. Sinarwati., dan N A S Dharmawan. 2015. Reaksi Pasar Modal Indonesia Terhadap Peristiwa Politik. E-journal S1 Ak Universitas Pendidikan Ganesha, Vol. 3, No.1, pp. 1-11.

9. Tandelilin, Eduardus. 2010. Portofolio dan Investasi. Edisi Pertama. Yogyakarta: Kanisius Najaf.

10. Yuliana, Yovinda T. dan I M. Sudana. 2015. Reaksi Pasar Saham terhadap Peristiwa Politik di Parlemen Indonesia tahun 2014. Jurnal Manajemen Bisnis Indonesia, Vol. 3, No. 1, pp. 14-28.

11. Yuniarthi, N. N. S. dan Sujana I K.. 2016. Reaksi Pasar Modal terhadap Pencalonan Jokowi Menjadi Presiden Republik Indonesia. E-Jurnal Akuntansi Universitas Udayana, Vol.16, No.2, pp. 951-977. 